\title{
Conversations with Russian mafiosi
}

\author{
Dina Siegel
}

Published online: 5 September 2007

(C) Springer Science + Business Media, LLC 2007

\begin{abstract}
Open interviews and unplanned conversations with criminals are an important part of ethnographic research in criminology. This paper presents an analysis of conversations with members of Russian criminal groups. An attempt is made to explore the value of these informal interviews, the danger of informal contacts with criminals, and the reliability of the information received.
\end{abstract}

Keywords Open interviews $\cdot$ Russian mafia $\cdot$ Ethnographic research $\cdot$ Organized crime

\section{Background of the research project}

The first alarm bells on the 'Red Mafia' in The Netherlands went off in 1994 when the Annual Report of the Dutch Secret Service (BVD) issued a serious warning to Dutch businessmen about to venture into Russia and predicted the Red Mafia's arrival in The Netherlands (Jaarverslag BVD 1994). Three years earlier, in 1992, the body of a murdered Russian had been found in Amsterdam. Allegedly he was the head of a gang of Russian extortionists operating in Belgium and The Netherlands. Another early story about the Russian Mafia had come from The Hague in 1994 where the local underworld had kicked a Russian-speaking mob out of the Red Light district. When the Russians were leaving the scene they left a message behind: "We'll be back!" Later it appeared that although they had failed in The Hague, Russians did succeed in pushing out local criminals from other red light districts, especially in the south of the country.

With the publication of the BVD report a first official message was formulated: The Russian Mafia is operating in The Netherlands and presents a threat to the Dutch

D. Siegel $(\square)$

Department of Criminal Law and Criminology,

VU University Amsterdam, De Boelelaan 1105, 1081 HV Amsterdam, The Netherlands

e-mail: d.siegel@rechten.vu.nl 
economy and democracy. ${ }^{1}$ Various reports from other countries, such as the USA, Germany, England, France and Israel confirmed that there was a potential threat of activities by the Russian mafia outside the former Soviet Union, particularly in countries of Western Europe (Varese 2001; Galeotti 1992, 1995; Ruthland and Kogan 1998; Williams 1997). Russian scholars emphasized the transnational character and 'global' intentions of the Russian crime organizations, which also contributed to the idea of a worldwide threat (Gurov 1995; Konstantinov and Dikselius 1997; Dolgova and Diakov 1996; Gilinskiy 1998, 2000). Russian criminologists and especially $\mathrm{MVD}^{2}$ officials warned against the potential expansion of the Russian Mafia around the world, since the Soviet Union was too small a territory for their activities (Gurov 1995; Konstantinov and Dikselius 1997).

These signals from different countries became even more threatening with the arrival of Russian-speaking immigrants in The Netherlands. After the disappearance of the Russian Jewish businessman Boris Fastovski in 1995 in Amsterdam the picture seemed to become even clearer: what was happening in other European countries, was about to happen here. The Russian mafia was on its way to The Netherlands, perhaps already active in some places. The wave of immigration from the former Soviet Union to The Netherlands in the years 1990-1996 and a series of liquidations and other criminal activities among the Russian speakers gave rise to questions about the link between the immigrant community and the Russian mafia. Dutch society seemed to be facing the presence of 'Russian mafiosi', not just immigrants who happened to speak Russian. Various institutions, including the police, the BVD, municipalities, press and media, financial and commercial organizations in The Netherlands were alarmed about this new phenomenon. The two main reactions of these institutions were fact finding and scientific research. In the period between 1996 and 2004, the Dutch government funded numerous investigations with the purpose of estimating the real threat of Russian organized crime.

While the press was collecting colorful stories about the bloodthirsty Russian Mafia, thereby creating a new 'public problem,' criminal analysts and the police were asking questions about numbers, names and types of criminal activities. Statistics were of little help because of the small numbers of Russian-speaking immigrants in The Netherlands. However, other data, such as illegal activities or the emergence of new forms of crime, provided enough material for a series of police reports. ${ }^{3}$

When taking into account that the Dutch government invested millions of euros in these police investigations (in 1998 and 1999 about 30 of the best Dutch police investigators and detectives were employed to find out the truth about the Russian Mafia), the seriousness of the problem looked even greater. The result was that the image

\footnotetext{
${ }^{1}$ RTL-4 News, 3 April 1995.

${ }^{2}$ Ministerstvo Vnutrennich Del (Ministry of Interior).

${ }^{3}$ In the period between 1995-1997 the following reports were published: Nulrapportage Oost-Europese criminaliteit in Nederland (January 1995), Staatscriminaliteit in (Sovjet)—Rusland (January 1995), PostSovjet criminaliteit-een internationale dreiging? (March 1996), Oost-Europese investeringen in Nederland (March 1996), De Russische Maffia. Nederlandse bedrijven en georganiseerde criminaliteit in Rusland (A. Jansen, March 1996), Afpersing door Oost-Europeanen (June 1996), Mensenhandel vanuit Centraalen Oost-Europa (February 1997), KT NON (Kernteam Noord en Oost Nederland), 1999, Oost-Europese georganiseerde misdaad: een bedreiging voor Nederland? Nijverdal, KT NON (Kernteam Noord-en OostNederland), 2000, Algemene Criminaliteitsbeeldanalyze Oost-Europa.
} 
of the Russian Mafiosi in The Netherlands, already established by the mid-1990s, was confirmed by these reports: There was a threat and something had to be done. Since the main suspects of Russian criminal activities were newly arrived immigrants and based on the international literature regarding the connection between crime and immigrant groups (Williams 1997; Bovenkerk 2001) the immediate question arose as to the possible link between the Russian Mafia and the Russian-speaking immigrant community.

The idea of the presence of the Russian mafia in The Netherlands suggested that one powerful criminal organization, with its headquarters in Moscow, had sent its agents around the world with the purpose to widen its markets and spheres of influence. Going across the border implied that the Russian Mafia was a transnational criminal organization (Williams 1995). The Russian criminals were believed to use immigrants as partners or clients of these activities, similar to what is happening in other immigrant criminal situations (see e.g. Bovenkerk 2001). This was the idea, but what was the reality?

My research was one of many studies conducted during these few years. It was financed by the WODC - Wetenschappelijk Onderzoek en Documentatie CentrumScientific Research and Documentation Centre at the Dutch Ministry of Justice. But, while the interest of the institution subsidizing the study was not different from other organizations, namely estimating the seriousness of the threat of Russian organized crime in The Netherlands, the purpose of my research had always been more than a description of organized crime among a group of Russian immigrants, or an analysis of statistical data. My study dealt with the Russian-speaking immigrants, and more specifically with questions of how they viewed and explained the activities of the Russian Mafia in The Netherlands. The main purpose was to understand the phenomenon called 'Russian Mafia' as perceived and explained by the Russian-speakers in The Netherlands themselves. This was actually one of the first attempts to study Russian organized crime empirically, from inside the community, by analyzing perceptions and conjectures of Russian speakers on Russian crime and violence in their midst. While many researchers have dealt with the subject over the last 10 years, none of them have concentrated on the insights of the Russian-speaking immigrants. They preferred to use police files, literature and interviews with the relevant officials. Rarely were the opinions of the Russian-speaking immigrants used as material for analysis (see Finckenauer and Waring 1998). I focused on the Russian speakers and examined how they viewed Russian organized crime activities in The Netherlands and what the differences were between their perceptions and those of the Dutch authorities. Therefore, informal interviews and conversations were an inevitable part of my fieldwork.

My material derived from my own observations, observations of respondents and interviews with several criminals in The Netherlands. The data gathering for the research lasted from March 1999 to March 2001. The core of my fieldwork was based on almost daily contact with 12 to 14 informants and their families, weekly meetings with about 16 to 18 others, open conversations (interviews) with 38 Russian-speaking legal immigrants and fourteen illegal immigrants and interviews with officials from various relevant institutions and organizations.

Although fieldwork is still not the most favored method of research in criminology, some empirical studies were conducted in this manner. During my research I came to understand that the results not only produced a supplement to the existing body of knowledge, but added another reality: the social construction of 
various definitions of Mafia, organized crime and violence and their relevance to Russians in The Netherlands.

\section{Interviews with the Russian Mafia}

In anthropological fieldworks interviews can be viewed as a social situation in which researcher and informant communicate in a more or less informal context, usually in the natural setting of the informant. In this regard, such interviews or conversations are different from the structured or semi-structured interviews used in sociological research. It can be compared with open interviews, although there are some differences, namely the spontaneous character and the possibility of unplanned questions resulting from the participant observation method. Access, setting and trust are the three most important factors in this context.

\section{Access}

Anthropological fieldwork methods, including conversations with criminal informants, have seldom been used in criminology. To begin with, there is the problem of access, especially in specific ethnic groups such as the Russians. Researchers have to be fluent in the language of the ethnic group they are studying or better still: They have to be 'one of them.' In the Russian community this may be difficult, since anyone who does not speak Russian is a 'foreigner' and therefore not to be trusted. This is a recognized cultural trait of the Russians, because Russians have always been acutely conscious of the distinction between 'insiders' and 'outsiders,' and they have taken this attitude with them wherever they went (Mosking 2001, p. 17). My Russian background was an advantage in this regard.

Secondly, there is the obstacle of how the informants will react to the subject of study in hand. It is important to introduce it in a way they understand. Acting on my existing knowledge of the general ideas about crime and illegality developed in Russian circles, I introduced myself by telling Russian speakers that I was studying the Russian business community in The Netherlands. Before approaching Russianspeaking immigrants with questions, I had to find a way to present myself and the subject of my study. It seemed clear to me at the time that it would not be possible to tell them about my interest in the Russian Mafia in The Netherlands. The most likely reactions would have varied from silence to laughter or jokes ('Do I look like a Russian mafioso?'). The next best thing I could think of was to tell my potential informants that I was writing a book on Russian business in The Netherlands. This sounded like a very neutral idea; there would not be any focus on specific individual businessmen or criminal activities. I also decided that I would not ask for official interviews or even names. The reactions I received came as a surprise:

- 'Oh, you write about business, you mean Russian Mafia!'-'Business? -You mean illegal business!'-'Russian business does not exist - there is only Russian Mafia!' 
My interest in 'business' was in many cases reduced by my informants themselves to 'illegal business' or 'organized crime' and the murdered businessmen were often used as examples. Also in my approach to respondents known in Russian circles as members of criminal groups, I talked only about business, without mentioning its criminal side.

New contacts were usually established via the snowball method, and I would either approach the potential respondent myself, or with the assistance and introduction of other respondents. Sometimes I had to be creative in accessing new contacts. In one case I first developed a relationship with the girlfriend of a Russian criminal. I learned that she took her child to the playground in the park on certain days of the week. I decided to take my sons to play there as well, and the first contact was created between two mothers instead of between informant and researcher. She and her boyfriend later became the most important respondents in my whole research.

\section{Settings}

Conversations with Russian criminals were part of my fieldwork among the Russian speakers in The Netherlands, particularly in Amsterdam. Therefore, most of the conversations were not planned or agreed on in advance. They took place on different occasions: parties, visits to Russian restaurants, in the park, in shopping malls. Once I had a conversation with B., a member of a Russian crime organization, in the Concertgebouw (Concert Hall) in Amsterdam during the performance of a Russian violin ensemble. I went to the concert with him, his wife, and two other Russian immigrants, but instead of entering the hall, I spent $21 / 2 \mathrm{~h}$ talking with $\mathrm{B}$. in the vestibule of the Concert Hall. Obviously, he was not interested in the concert itself, and used the opportunity to escape his wife's company. For me it was a unique opportunity to spend time exclusively with B., to ask him questions and to listen to his story.

There were also cases of 'arranged' interviews. I asked one of my respondents to set up a meeting with S., a member of a Baltic criminal group. S. agreed to talk to me in the lobby of one of the luxury hotels in Amsterdam. We sat in the lobby drinking coffee in a relaxed atmosphere. I did not use my notebook on S's request; we just talked about his life. After a one-hour conversation S. left. When I was on my way out, I was approached on the staircase by one of the hotel managers who asked me if I knew that the person I had been talking to was a Russian Mafia boss! He also asked me whether I was a journalist and if so, not to mention the name of his hotel to avoid negative publicity. I was later told by other respondents that $\mathrm{S}$. was a well-known figure in the local Dutch underworld.

Trust

The trust of my informants was vital in building relationships and gathering valuable information. I always promised discretion. In most cases they saw me as a 'writer' or a university researcher. My informants, who made the connection to cultural values they held in high esteem (education and erudition), always respected the academic background of the research. One informant, himself connected to Russian criminal 
groups, used to send me e-mails with Russian media articles on a specific crime boss ('for your business book').

While my efforts to get access and to build trust appeared to be going along smoothly, and important contacts were established, expectations were created on the side of the respondents. The main question to arise at this phase was: why do people talk? The answer was that they were mostly driven by self-interest. When they provided me with important information, these respondents expected something in return, for example revenge. They wanted to publish the 'truth' about their business rivals, allegedly involved in illegal activities or connected to criminal organizations. In these cases, when their purpose became clear to me, I had to be especially careful with my facts, and check them even more thoroughly than in other cases, in order not to ruin the reputation of persons involved and to avoid becoming a tool in the hands of informants with an agenda. Mostly, this kind of information served as a starting point for further investigations, during which I tried to collect additional relevant information from other sources. Sometimes, the information was controversial and if I could not get a clear picture I chose to present all possible arguments from different sources, or to drop the case completely.

\section{Problems}

There is a problem of ethical restraint. Some criminologists have ethical objections to field research among criminals (Sutherland and Cressey 1960, p. 69). Trying to get closer to informants, however, does not necessarily mean identifying with them. I often had to deal with the question of ethics. In empirical research, tension can exist between the need to protect the research population (from violent retaliation, capture, defamation or privacy intrusion), and the need to inform about harmful or criminal offences (to other informants or to the police) that come to the knowledge of the researcher. The information derived from my interviews was no exception. I always gave priority to protecting informants as long as I was not directly confronted with serious violent crimes or risks. Luckily I did not experience such extreme situations.

Another reason why fieldwork is not very common in criminology is the problem of danger. Some criminologists have emphasized that the empirical study of organized crime is dangerous (e.g. Finckenauer and Waring 1998, p. 7). I never looked at my informants as dangerous criminals. In this regard, a professional approach is important: one has to make a distinction between his/her role as a researcher with a scientific and neutral attitude and as a civilian with morality and social responsibility. For me criminals were a source of important information and usually I was grateful to them for sharing this information with me. Therefore, the 'danger' aspect of being involved with criminals was not that relevant. However, the consequences of using information provided by criminals can be unsafe. To avoid dangerous situations I was always alert to the warnings of my informants. All my informants were fully aware of the fact that I was writing a book and that many of our joint activities would be used as ethnographic material. Sometimes I was asked 'not to mention' some information, or it was emphasized that something was confidential or 'for your ears only.' In these cases I decided to respect their wishes, also because of the importance of the relationship of trust with my informants. 
Although I was explicitly looking for cultural interpretations of crime (and this includes a certain degree of subjectivity per se), one of the problems I faced during my fieldwork was that my informants often told me different versions of the same event. In one case, I heard seven different versions and interpretations of a murder story and the reasons for the victim's death (from contract killing to leukemia). In another case, there were different versions regarding the ethnic group the offenders belonged to: some informants blamed Chechens, others Georgians, one informant mentioned Turks. In spite of the relationship of trust I had built with my informants, the problem of getting reliable information remained a constant factor during the fieldwork.

Often informants were unable to tell me whether their specific information was derived from their own experience, from other people's stories or from the Dutch media. Similar problems have been discussed by Finckenauer and Waring in their study of the Russian Mafia in the USA: 'it was often difficult for them (Russian immigrants) to identify where a particular piece of information or an impression had come from' (1998, p. 122). In such situations additional sources of information were vitally important. During my conversations with Russian criminals two specific methodological problems presented themselves, namely gossip and lies. In many cases informants simply made up their stories, or invented details. The next day they would not remember what they had told me the day before. In some cases I felt they tried to impress me with their expertise and erudition. Sometimes they were simply lying. This does not mean that their information was irrelevant. On the contrary, I tried to understand why they lied, and in what cultural context their lies and lack of trust towards each other should be seen. I wondered whether gossip was really an obstacle to scientific research or whether it illustrated a specific cultural trait (for example mutual distrust), or the continuity of a tradition brought from Russia to The Netherlands, or even more importantly: the manner in which people construct reality. This is why I will now focus briefly on lies and gossip, not only as an obstacle, but also as a source of information which can provide an additional explanation to the issue of how my informants arrived at certain perceptions of reality.

According to some authors, the Soviet people have maintained a 'tradition of lying' during the seventy years of the Soviet regime: 'People easily protect their private life because they are forced to lie regularly in their professional work, faking reports on their production activity, pretending to fulfil orders, and participating each day in the various rituals' (Shlapentoch 1989, p. 159). This explanation emphasizes the continuity, but it does not explain the reason why the lies persisted after 1991, or why citizens of the former Soviet Union would still be lying in a totally different country and social environment.

Gossip as a way of communication is more common. In a moral sense gossiping is considered a negative, but criminologists have found that it can play a functional role in uniting people and in the exertion of social control. According to Paine "...sometimes a good gossiper plans on certain of his "confidences" being passed on; at other times the social costs to him of a leakage would be disastrous' (1967, p. 283). By gossiping one is able to manipulate the construction of specific images or ideas. In one case a former partner of G., a dubious Russian businessman, spread the rumor that G. was 'mixing with some suspicious guys', with the clear purpose of spoiling his reputation in Russian circles, and especially among his clients. In another case, the wife of V., another Russian businessman, told me that she almost divorced 
him, when 'a good friend' told her that there were rumors of V. using his extended business trips to Russia as an excuse to stay with his mistress. As V. found out later, the gossiper was one of his former clients, who had promised to 'punish him' for not living up to a business contract. In these cases gossip created a lack of trust, but also valuable information on competitors and rivals. This led me to conclude that although rumors and lies can be an obstacle to gathering information, they still play an important role in the process of the respondents' self-identification and construction of images. In a scientific analysis gossip and lies should not be neglected as 'unusable material.' On the contrary, they can provide us with more insight and a deeper understanding of the cultural construction of images of crime among Russian speakers in The Netherlands.

\section{Value of interviews}

The question I often asked myself during my research was whether I could obtain the same data and results by using alternative research methods, such as analyzing police files or interviewing prisoners, but the answer must be negative. In files or interviews detainees tend to present only information they consider to be in their own interest: to get released from prison or to be found not guilty. This type of data can never provide us with much insight into motives, background, the informants' context and networks, or the 'essence' of the crime committed. Moreover, crime consists of more than facts and numbers: 'crime is as much about emotions, hatred, anger, frustration, excitement and love - as it is about poverty, possessing and wealth' (Presdee 2004, p. 4). In conversations with criminals these important factors are present and can be studied. This is particularly valuable for a better understanding of the motives and perceptions of crime as explained by the informants themselves.

\section{References}

Bovenkerk F (2001a) Organized crime and ethnic minorities: is there a link?, In: Williams P, Vlassis D (eds) Combating transnational crime. Concepts, activities and responses. ISPAC, A Frank Cass Journal, Milano

Dolgova A, Diakov S (eds) (1996) Organized crime-3. Criminological Association, Moscow

Finckenauer J, Waring E (1998) Russian mafia in America: immigration culture and crime. Northeastern University Press, Boston, MA

Galeotti M (1992) Organized crime in Moscow and Russian National Security. Low Intensity Confl Law Enforc 1/3:237-252

Galeotti M (1995) Mafiya: organized crime in Russia. In: Jane’s Intelligence Review (special report), no. 10

Gilinskiy Y (1998) The market and crime in Russia. In: Ruggiero V, South N, Taylor I (eds) The new European criminology. Crime and social order in Europe. Routledge, London

Gilinskiy Y (2000) Crime and deviance: stare from Russia. St. Petersburgh Institute of Sociology, St. Petersburgh, Russia

Gurov A (1995) Krasnaya Mafia, 'Samotzvet' Miki 'Kommerchiskyi Vestnik,' Moscow

Konstantinov A, Dikselius M (1997) Banditskaya Rossiya. St. Peterburg 'Bibliopolis.' Moskva 'Olma Press' Mosking G (2001) Russia and the Russians. The Penguin Press, London

Paine R (1967) What is gossip about? An alternative hypothesis. Man 2(2):278-285

Presdee M (2004) Cultural criminology: the long and winding road. Theor Criminol 8(3):275-285

Ruthland P, Kogan N (1998) The Russian mafia: between hype and reality. Transitions 5(3):24-34

Shlapentoch V (1989) Public and private life of the Soviet people. Oxford University Press, Oxford 
Sutherland, Cressey (1960) Principles of criminology, 6th edn. J. B. Lippincott, Philadelphia Varese F (2001) The Russian Mafia. Private Protection in a New Market Economy. Oxford University Press, Oxford

Williams P (1995) The new threat: transnational criminal organizations and international security. Crim Organ 9(3/4):3-20

Williams P (ed) (1997) Russian organized crime. the new threat? Frank Cass, London 